\title{
MENINAS ÓRFÃS, IRMÃS VICENTINAS E PROFISSIONALIZAÇÃO FEMININA NO SÉCULO XIX EM FORTALEZA (CE)
}

ORPHANED GIRLS, VINCENTIAN SISTERS AND PROFESSIONALIZATION IN THE 19TH CENTURY IN FORTALEZA (CE)

Ana Cristina Pereira Lima* anacris.historiaufc@gmail.com

RESUMO: Este artigo trata do contexto de instalação do Colégio da Imaculada Conceição no Ceará. Na metade do século XIX, vários discursos e práticas sobre a educação feminina viraram pauta importante na imprensa e na legislação, indicando a atuação de diferentes agentes na fabricação ideal de mulher e de mãe. A partir de periódicos do período, fontes oficiais, regulamentos do Colégio, romances e livros de memória é possível analisar o cotidiano de meninas pobres que recebiam educação profissional e religiosa no recolhimento organizado pelas Irmãs de São Vicente de Paula. O orfanato do Colégio da Imaculada Conceição em Fortaleza (CE) não era um simples abrigo; era uma instituição voltada à preparação de órfãs para o trabalho.

PALAVRAS CHAVE: Infância pobre, Vicentinas, Educação feminina.

ABSTRACT: This article deals with the installation context of the Colégio da Imaculada Conceição of Ceará. In the middle of the 19th century, speeches and practices on female education were in the press and in legislation. Many agents have built an ideal model of women and mothers. Based on periodicals, official documents, school regulations, novels and memoirs, it is possible to analyze the lives of poor girls who received professional and religious education in the orphanage of the Sisters of São Vicente de Paula. Colégio da Imaculada Conceição in Fortaleza (CE) was an institution dedicated to the preparation of orphans for work.

KEYWORDS: Poor childhood, Charity Sisters, Education for women.

\section{A Educação feminina nos Oitocentos: fabricando mães, contendo mulheres.}

O ponto de partida de quase todas as argumentações em prol da educação feminina era, na metade dos oitocentos, a ideia de civilidade. Defendia-se que para haver notável melhoria na Nação, era preciso diminuir o número de analfabetos, disseminar a cultura letrada, ensinar novos modos e gestos que seriam sinônimos de progresso. Em parte alguma, essas questões foram levantadas como ideais de igualdade. A educação, como componente político, jamais esteve apartada das diferenciações sociais, dos aspectos étnicoraciais e de gênero. Os discursos de modernização do Brasil asseguravam interesses de grandes proprietários e da crescente diversificação dos negócios, principalmente nos setores do comércio e da insipiente indústria brasileira. Ainda assim, os slogans de civilidade e progresso nacional, estampavam propostas generalizantes e um tanto superficiais sobre as vantagens de instruir o povo. Nessa conjuntura, a necessidade de educar as mulheres

\footnotetext{
* Doutorado em História pela Universidade Federal do Ceará. Professora do Instituto Federal de Educação, Ciência e Tecnologia do Rio Grande do Norte.
} 
ganhou destaque, evidenciando noções de educação assentadas nas definições de papeis sociais femininos atrelados, necessariamente, à função de mãe. Assim, ampliou-se o número de escolas femininas, tanto públicas como privadas.

Havia uma circulação de discursos que endossavam o víeis moral da educação como prioridade para as mulheres. A construção e as tentativas de sedimentação de valores como honra, fidelidade da mulher e maternidade abnegada contaram com a imprensa do período, que funcionou como importante aparelho de regulação. Esse processo de simbolização do feminino ao mesmo tempo em que outorgava preceitos e comportamentos esperados (considerados, por isso, mais corretos) servia para justificar as ações normatizadoras do Estado com relação às famílias. Entretanto, ainda que muitas mulheres se ressentissem (ou admitissem algum arrependimento publicamente) dos supostos "erros" cometidos com relação à virgindade ou gravidez "ilegítima" (condição das mães solteiras), esses discursos moralizantes foram cotidianamente afrontados. Ou seja, o domínio dos espaços de divulgação dos discursos - tais como a imprensa, a justiça, a escola - combinado ao silenciamento dos saberes e experiências das mulheres nos oitocentos - especialmente as chefes de família - pôde pronunciar e até popularizar um protótipo de mulher "descente". Mas jamais pôde apagar as divergências e nem produzir unanimidade. Por mais que mulheres pobres (e mesmo as que não eram pobres) identificassem as características e possíveis virtudes desse modelo ideal, muitas delas seguiram caminhos opostos. Assim, a proposta de educação feminina no século XIX era uma forma deliberada e politicamente engajada de tentar sobrepor os valores de honra e casamento aos códigos comportamentais identificados com outros sentidos de família, de prazer e de afetos.

Essas noções de honra familiar e a preparação das mulheres para o casamento estiveram no cerne de questões jurídicas, médicas e educacionais ao longo de todo século XIX. Sueann Caulfield (2000) analisou os embates entre juristas brasileiros acerca dos princípios legais sobre honra e moralidade, construídos no Império, que ultrapassaram o século XIX e permaneceram - não sem controvérsias - ao longo das primeiras décadas do Regime Republicano. O código criminal, elaborado em 1830, quando o Brasil era regido juridicamente pelas leis das Ordenações Filipinas, apresentava acentuado caráter liberal, cuja premissa estava na defesa da liberdade individual e na noção de igualdade da responsabilidade criminal para todos. Entretanto, como observou a autora, alegando a 
suposta permissividade da lei a respeito da insubordinação dos escravos e revoltas populares, os legisladores imperiais modificaram o código de 1830 para adequá-lo às suas conveniências. O fundamento dessas mudanças era diferenciar criminosos e vítimas a partir das condições sociais. A ideia liberal de igualdade perante a lei fora, progressivamente, suprimida da legislação para manter privilégios senhoriais. Especificamente sobre os crimes contra a honra, o que prevaleceu foram juízos pautados na cor e na condição social, que para Caulfield, tornava impraticável a definição de critérios objetivos para julgar a honra das mulheres.

Quando da construção e promulgação do código penal de 1890, os debates sobre a instituição familiar e a honra que deveriam aparecer de forma "modernizada" no Brasil Republicano, revelaram intensas disputas teóricas entre os juristas. Sueann Caulfield fez notar os choques entre os defensores do "direito clássico" - ala mais tradicional, que tentava manter certos privilégios de classe a partir da defesa da responsabilidade penal individual - e a chamada "escola positiva" - que mesmo com muitas discordâncias, eram reconhecidos por se basearem nas ideias de Auguste Comte (e outros pensadores europeus) sobre o progresso humano e o desenvolvimento científico, que abria espaço para os postulados criminais pautados em fatores biológicos e sociológicos. Essa discussão, muito ampla e complexa, trazia a necessidade, defendida por juristas, médicos e educadores da época, de intervir no desenvolvimento moral da população brasileira. Todos esses debates e questionamentos jurídicos estiveram presentes na composição do primeiro código civil brasileiro (1916) - que a despeito das tentativas de Clovis Beviláqua e outros juristas reformadores - "reproduziu as diferenças de gênero que distinguiam sujeitos jurídicos 'capazes' e 'incapazes' das Ordenações Filipinas" (CAULFIELD, 2000, p. 64). Com poucas modificações, as mulheres continuaram a ser tratadas como entes incapazes de autonomia civil, sob a mesma lógica que, durante o século XIX, impedia as mães de desempenharem o pátrio poder sobre seus filhos. Dessa forma, nota-se uma longa trajetória de produção de sentidos e práticas assentadas na supressão legal da liberdade feminina em prol da instituição familiar.

A análise de Caulfield permite entender que as noções de moralidade e honra (assimiladas ou não) em vigor no início do século XX foram resultado de um longo percurso histórico, que no Império assim como na República, estiveram saturadas de elementos 
raciais e de classe. A autora ainda aponta para a incompatibilidade entre a defesa da igualdade civil e as tentativas do poder público de guardar a honra feminina. Ou seja, falavase de modernizar o Brasil em fins do século XIX e de inaugurar uma cidadania republicana mais próxima das noções de progresso em voga, ao mesmo tempo em que defendiam o modelo "corporativo de família" - em que as discrepâncias de gênero eram reafirmadas na legislação.

Esse debate não se restringiu ao campo jurídico, embora a apreciação das formulações legais, bem como o ideário médico-higienista e a fabricação da modernidade a partir do conceito histórico de família, ofereçam indícios importantes para entendermos a sustentação, a circulação e as transformações das ideias sobre os lugares de atuação da mulher no século XIX (SANT'ANNA, 2011 e ENGEL, 1997). Percebe-se assim, que os discursos sobre educação feminina na metade dos oitocentos, nitidamente preocupados com a honra familiar - ainda que esta expressão tenha infinitos significados - não eram isolados ou atípicos.

Com ou sem instrução para as mulheres, o ponto em que jornalistas, escritores e outros veículos de opinião convergiam era a educação feminina como componente de modernização da família, projetando na mãe uma tendência ao melhoramento gradual de gerações vindouras. Tais preocupações pertenciam ao campo das subjetividades morais, tanto laicas quanto católicas, que nas décadas de 1860-70 - ao menos na imprensa cearense - ganhavam forma nos conselhos dados às mulheres, às vezes até contendo listas de tarefas de como proceder "honestamente". Em fevereiro de 1868, o jornal Pedro II publicou um artigo, no qual associava a educação da mulher à "paz doméstica". Em linhas gerais, afirmava que a primeira coisa a ser ensinada a uma mulher era que devia "evitar sempre contradizer seu marido". Nesse texto, o resultado da boa educação seria o governo da família, que, segundo o autor, só se alcançaria a partir de dois meios: "um pela expressão da vontade, que pertence à força; o outro pelo irresistível poder da doçura, que é muitas vezes superior à força. O primeiro pertence ao marido - a mulher só deve usar o segundo" (Pedro II, ed.31, p. 2, 8 fev. 1868). Esse tipo de argumento não desapareceu dos jornais ao longo do período estudado. Contudo, outros arcabouços teóricos - que apenas na forma se afastavam dessas apreciações morais - foram sendo formulados nas décadas finais do século XIX, identificados, à época, como legitimamente científicos. 
A educação moral aliara-se aos discursos e métodos de melhoramento racial. Conforme observou Fonseca (2015), no Ceará, as vertentes filosóficas do Evolucionismo e Darwinismo Social começaram a aparecer na imprensa na década de 1870, especialmente tentando explicar as relações entre raça e meio natural. Essa discussão ganhou notoriedade entre os intelectuais cearenses, cujos clubes literários, jornais e revistas científicas dos anos de 1880 fizeram circular estudos sobre o perfil do povo cearense e o melhoramento da sociedade. Em meio à difusão dos ideais de higiene física, mental e social, uma forte ligação entre educação e eugenia ia sendo gestada no Brasil na passagem do século XIX para o XX. Nessa perspectiva, a instrução era imprescindível também para as mulheres. O processo que Vera Marques (2004) nomeou de "constituição dos sujeitos eugênicos" tomou o ensino e a normatização do ambiente escolar como uma de suas bases de irradiação. $O$ entusiasmo pela educação como lócus de salvação da pátria e o alcance das teorias raciais sobre degenerescência e aperfeiçoamento humano fizeram multiplicar os discursos pró-eugenia nos anos 1920-30. As formas arbitrárias de implantação do saber eugênico foram analisadas pela autora como instrumento de controle da população, indicando que a escola foi um centro difusor das práticas eugênicas, demonstrando "uma simbiose perfeita da educação moral com a educação higiênica dos corpos" (MARQUES, 2004, p. 107).

Não é o propósito deste artigo se demorar no debate sobre as questões próprias do saber médico-higienista no Brasil e suas inferências na política e nos projetos educacionais. Pretende-se, no entanto, pontuar que a educação feminina estava inserida dentro de um importante campo de embates sobre a família, os sentidos da moralidade e as vontades / projetos de modernização nacional. O olhar eugênico sobre a educação e sobre a mulher (na medicina e no plano social) intensificava a responsabilidade feminina com o porvir. De outros modos e sob outros paradigmas - agora como força de verdade científica - a mulher continuava na ambígua situação de problema/solução da humanidade. Ainda que jurídica e politicamente inferiorizada nas questões econômicas e de domínio sobre os filhos e sobre a própria honra, cabia à mulher o lugar de saneadora dos males de infância, devendo preparar nos filhos cidadãos úteis para o futuro da Nação. A multiplicidade de opiniões e poderes que incidiam sobre a instrução (ou não) das mulheres no século XIX evidenciam que as inquietações não eram só quanto à forma (na escola ou em casa?) ou ao conteúdo (geografia ou piano?) da educação feminina. 
Muito antes de ser difundida na imprensa cearense qualquer teorização sobre eugenia - ainda que os desejos de "saneamento social", avant la lettre, perpassassem as opiniões de políticos e homens de letras desde os anos 1850 - o debate específico sobre a educação das meninas pobres começava a se insinuar na esfera pública. Quando se tratava da educação de meninas pobres, não era somente a honra e o exemplo de mulher ideal que importava. Era preciso preparar essas meninas para o mercado de trabalho, para serem úteis e produtivas na construção da nação "moderna".

\section{O Colégio da Imaculada Conceição em Fortaleza (CE)}

Depois de uma epidemia de Coléra-morbus no Ceará (1862), que afetou mais severamente as cidades de Icó e Aracati, acompanhou-se uma intensa campanha de arrecadação de recursos destinados à assistência infantil. No final do referido ano, o presidente da província em viagem ao Rio de Janeiro, conseguiu uma subscrição disponibilizada pelo desembargador Figueira de Melo em favor das vítimas da epidemia caridade alardeada nos jornais (Cearense, ed. 1548, p.1. Fortaleza, 28 out 1862). Como o valor era bem expressivo para o contexto (dez contos de réis), especulou-se sobre o destino que deveria ter o dinheiro. Na ocasião, o bispo do Ceará, D. Luiz Antônio dos Santos, sugeriu a criação de um colégio de órfãs, o que motivou a campanha, divulgada amplamente na imprensa local. Diante do argumento de que distribuir o dinheiro para os lugares mais afetados pela doença surtiria pouco efeito, pensou-se em empregar o recurso em algo mais organizado, como uma casa de caridade. Assim, o presidente da província criou uma caixa beneficente para atender "a pobreza honesta e desvalida" e "amparar as órfãs que a epidemia deixou na miséria", conforme notícia oficial (Gazeta oficial do Ceará, ed. 113, p. 4, Fortaleza, 12 dez 1863). Por intermédio do bispo, as Irmãs de São Vicente de Paula vieram da França para organizar um colégio para as órfãs, onde meninas pobres seriam internadas e receberiam instrução primária e profissional.

O dinheiro da caixa beneficente foi aplicado na reforma, mobiliário e manutenção da casa onde deveria ser o colégio das órfãs, inaugurado em 1865. Entretanto, o projeto inicial foi rapidamente remodelado e as Irmãs Vicentinas no Ceará passaram a atender moças ricas, como já acontecia em outras províncias brasileiras. Em razão do crescimento do número de pensionistas (garotas internas cujas famílias custeavam a permanência), demandou-se um prédio maior. Em 1867, a Diocese conseguiu negociar com o Governo 
Provincial a concessão do edifício que pertenceu ao Colégio de Educandos Artífices, desocupado no ano anterior. A partir daí, a "casa das órfãs" passou a ser oficialmente chamada de Colégio da Imaculada Conceição (CIC). As antigas dependências do Colégio de Educandos Artífices - que recolheu meninos órfãos para o ensino profissional entre os anos de 1856 e 1865 - foram reformadas e as meninas divididas em duas alas de alojamento (uma para as pensionistas e outra para as órfãs). Meninas de várias cidades cearenses foram matriculadas como pensionistas ou recebidas como órfãs. Além da concessão do prédio, o Governo da Província liberava três contos de réis anuais para o recolhimento de órfãs tuteladas pelas Irmãs de Caridade.

Diante do panorama educacional cearense, marcado pelos altos índices de analfabetismo, pelas preocupações morais em torno da educação feminina e pelas dificuldades de habilitar moças para o magistério (a Escola Normal no Ceará só foi inaugurada em 1884), a educação confessional pareceu para muitos uma ótima aliada no projeto de ampliação da instrução pública na província. Afinal, padres e freiras possuíam instrução suficiente para se tornarem professores além de estarem, supostamente, acima de qualquer suspeita moral. Todavia, os defensores das ideias liberais não foram tão receptivos à presença das irmãs de caridade nos espaços que recebiam subvenção estatal, como no Colégio da Imaculada Conceição. Grande parte dos liberais apoiava o ensino laico sem, no entanto, se posicionarem contrários à Igreja Católica. Por diversas vezes, o jornal Cearense órgão do Partido Liberal - declarou apoio ao Bispo, especialmente no processo de instalação do Seminário, quando D. Luiz recorreu ao governo provincial em busca de um prédio para abrigar padres e seminaristas.

A defesa do ensino laico ganhou maior destaque com publicações ligadas aos intelectuais maçons, cujas ideias foram divulgadas em Fortaleza no jornal Fraternidade no início da década de 1870. Segundo Berenice Abreu de Castro Neves (2002), tais intelectuais da Maçonaria combatiam o conservadorismo católico e defendiam ideias liberais e iluministas, levantando questões jurídicas e políticas em torno do regime de padroado, que unia oficialmente o Estado à Igreja Católica no Brasil. Como incentivadores do saber científico e humanista, os maçons afirmavam que a ignorância do povo era promovida pela própria Igreja com finalidade política. Além de se oporem à formação religiosa e às aulas de doutrina católica nas escolas públicas, criticavam severamente as instituições católicas 
voltadas à infância desvalida, como o Colégio da Imaculada Conceição, instituição que mantinha evidentes as discriminações sociais já que pensionistas e órfãs não recebiam tratamento equivalente.

A difusão da educação confessional que tanto incomodava intelectuais maçons e outros iluministas brasileiros fazia parte de um amplo processo de reorganização da Igreja Católica e fortalecimento do pontificado no século XIX denominado de Romanização - um esforço de unificação doutrinária do clero disciplinado pelo papa (europeização do catolicismo), reelaborando seu perfil institucional (SOUZA, 2002). Contudo, a vinda das irmãs de caridade e seu projeto de assistência aos pobres não se reduzia à seara religiosa. As vicentinas ingressaram abertamente no meio desses embates, construindo espaços de atuação que, mesmo sem pronunciamento direto na imprensa, as colocaram como notáveis protagonistas da educação para "desvalidos" em várias províncias brasileiras. As disputas intelectuais, as formas de idealizar e praticar a educação feminina salientam a gama de sentidos políticos intrínsecos à implantação do recolhimento de órfãs em Fortaleza.

Com o acirramento dos debates sobre a educação confessional e a crescente divulgação do cientificismo e das ideias liberais de forma geral na década de 1870 , o subsídio de três contos de réis anuais que a Tesouraria Provincial destinava à administração vicentina passou a ser questionado. No final de 1879 , foi posta em votação na Assembleia Provincial a concessão de mais dois contos de réis ao Colégio que, em decorrência da grande seca iniciada dois anos antes, reclamava o reajuste da verba por conta do "crescimento extraordinário de órfãs" acolhidas. Na ocasião, o deputado João Lopes se pronunciou contra à subvenção, justificando que o estabelecimento não estava "absolutamente sujeito aos poderes públicos, de nenhum modo subordinado a autoridade civil; a única autoridade com que se entende é o bispo". O deputado ainda argumentava que ninguém do governo, nem o diretor da instrução pública, sabia como era aproveitado esse dinheiro e foi apoiado por vários outros legisladores ao sugerir a fiscalização da referida despesa. A discussão esquentou quando João Lopes disse que, como o Colégio não estava organizado dentro das normas da instrução pública da província, "a irmã de caridade não esta[va] no caso de ocupar a cadeira de mestra". Nesse ponto, muitos discordaram e fizeram seus apartes defendendo a competência pedagógica e moral das Irmãs. O comentário foi, então, retirado, 
mas o voto contrário permaneceu (Cearense, ed. 121, p. 3, 1 nov. 1879). Encerrada a sessão, manteve-se a subvenção original, que alcançou a década de 1930.

Do debate exposto acima é possível sublinhar três questões fundamentais: em primeiro lugar, a ideia de recolhimento de aspecto caritativo, ainda que repleta de contradições discursivas, fora apoiada pelo governo durante todo o período imperial. Mesmo em momentos de retração econômica (como nos anos de seca), ou exatamente por isso, o Estado continuou apostando no recolhimento e na institucionalização da caridade como projeto político de assistência à infância pobre. Em segundo lugar, a atuação das Irmãs Vicentinas e a autonomia de suas práticas pedagógicas eram contestadas, mas o lugar social que tomaram para si no cuidado e disciplinamento dos pobres era de difícil desconstrução. A competência intelectual e a moralidade das freiras, ainda que não gozassem de unanimidade, eram pouco contestadas. Por fim, apesar de o ensino confessional subsidiado pelo erário público virar alvo de crítica dos liberais, o ensino religioso (católico) estava longe de desaparecer da instrução pública.

Assim, o Colégio da Imaculada Conceição se manteve como principal referência de educação feminina na cidade de Fortaleza durante o século XIX. Como essa intuição de ensino, pautada na caridade cristã, implementou o recolhimento de meninas pobres e tributou para o projeto de formação para o trabalho no período?

O projeto de recolhimento das meninas em uma "casa de órfãs" não era um ensaio de ingresso na vida religiosa. Era, acima de tudo, uma preparação para o trabalho doméstico qualificado e reportado à obediência cristã. Segundo Juliana Linhares (2011), houve uma sensível mudança na organização do trabalho doméstico no século XIX. As discussões sobre o fim da escravidão e as propostas de desintegração gradual do trabalho escravo fizeram aumentar a preocupação das autoridades governamentais com os deveres e comportamentos de criados e empregados domésticos, culminando num regulamento específico sobre essa categoria na capital cearense. A partir de 1881, todos os criados deveriam ser registrados na secretaria de polícia, recebendo uma caderneta que autorizava sua contratação. Nas décadas de 1870/80 uma série de posturas municipais regulava as relações entre patrões e empregados domésticos, quase sempre apontando fatores de cunho moral para justificar as demissões por justa causa. Nesse sentido, o recolhimento de meninas pobres no colégio das irmãs passou a dialogar com esse aparato de controle do 
serviço doméstico, onde se concentrava a maioria das mulheres trabalhadoras do período. Inaugurado na década de 1860, já percebia nas meninas internadas possíveis braços para as casas abastadas de Fortaleza, correspondendo às demandas pelo trabalho doméstico disciplinado, que, paulatinamente, foram sendo transmitidas pela imprensa e pela legislação.

Recolhimento e trabalho infantil: a profissionalização de meninas pobres

No mesmo ano em que as Vicentinas, suas pensionistas e órfãs recolhidas se mudaram para o prédio do extinto Colégio de Educandos, uma festa de natal foi organizada para distribuir os prêmios de honra ao mérito às educandas que se destacaram "por sua aplicação e conduta". A festa contou com a presença do bispo Dom Luiz, representantes do Governo e redatores de alguns jornais de Fortaleza (Pedro I/ e Cearense). Na ocasião houve uma exposição dos trabalhos das pensionistas e das órfãs, com destaque para as obras em lã e bordados a fio de ouro. Ali, em dezembro de 1867, as meninas se despediram das Irmãs para passarem as férias de natal com suas famílias. As órfãs permaneceram no Colégio (Cearense, ed. 2525, p. 1.12 dez. 1867).

Anos depois, quando as Irmãs ampliaram o atendimento às meninas "desvalidas" com a criação do Externato São Vicente de Paula (1887), a cerimônia de Primeira Eucaristia também foi noticiada pelos jornais. Celebrou a missa o bispo D. Joaquim, que fez "nobre e eloquente oração" pelas Irmãs, que tratavam "aquelas mocinhas como filhas". Foi oferecido um almoço aos convidados e às famílias das pensionistas que, naquele dia, também recebiam sua primeira comunhão. "O serviço foi perfeitamente feito pelas órfãs", como destacou o jornal Cearense. À tarde, as meninas participaram de uma procissão para coroação de Maria. As alunas foram divididas em duas alas: uma longa fila de alunas do externato e de órfãs internas e uma outra fila de pensionistas. Ao final da cerimônia, todas as órfãs se retiraram com "maior respeito, boa ordem e regularidade desejáveis", retornando ao Colégio (Cearense, ed. 246, p.2. 3 nov. 1887).

Entre os dois eventos passaram-se vinte anos. Outras festas e celebrações organizadas pelo Colégio da Imaculada Conceição foram narradas, elogiadas pela imprensa, cujas descrições revelaram, com naturalidade, as diferenças entre pensionais e órfãs. As falas diocesanas e os fragmentos do cotidiano escolar que apareciam de relance nas notícias mostraram que esse elemento de segregação perpassou a proposta educativa das Irmãs de 
Caridade como componente disciplinar, sob o argumento de que o ensino religioso produziria a concórdia, independente das diferenças sociais. Entretanto, o convívio de meninas pertencentes a camadas sociais distintas não acontecia sem embates. Em Minas Gerais, como observou Ana Cristina Lage (2011), as Irmãs enfrentaram a resistência das famílias ricas ao propor na década de 1850, como princípio de valorização do trabalho, que as meninas cuidassem de seus próprios dormitórios e vestes. As noções de trabalho no Brasil oitocentista eram bem diferentes das francesas, culminando em verdadeiro incômodo o serviço de limpeza - próprio de criadas. Outro impasse encarado pelas vicentinas na cidade de Mariana foi quanto à coabitação de órfãs mulatas e pardas com as meninas abastadas. Ali, a ampliação do número de pagantes resultou em dois colégios distintos, um para pensionistas ricas e outro para as órfãs desvalidas.

No Ceará, habitando o mesmo prédio, as meninas pobres tiveram que conviver com enormes barreiras físicas e simbólicas. Esses momentos festivos, em que o público conseguia perceber facilmente as diferenças entre pobres e ricas expressavam certa negociação entre as famílias pagantes e o modelo de convívio proposto pelas freiras. Ou seja, se não houve, no caso de Fortaleza, uma separação rígida entre o recolhimento de órfãs e o internato de mocinhas ricas - ao menos em se tratando do prédio -, foi preciso tornar socialmente evidente que essa aproximação não significava qualquer nivelamento entre as meninas. Assim, o fato de meninas órfãs servirem o jantar nas comemorações do Colégio não era apenas uma questão de praticidade e economia. Não estavam exercendo papel de anfitriãs. Essas ações davam a ver para a cidade que meninas órfãs não estavam sendo comparadas às "meninas de boa família".

Uma vívida imagem dessa separação foi formulada por Rachel de Queiroz no romance As Três Marias, publicado originalmente em 1939. Na narrativa, o Colégio fora descrito como uma cidadela de muros altos, que guardava a todas dos contatos externos, mas dividido em realidades bem distintas:

De um lado vivíamos nós, as pensionistas, ruidosas senhoras da casa, estudando, tocando piano, vestindo uniformes de seda e flanela branca. Ao centro, era o "lado das Irmãs", onde não entrávamos nunca. E além, abrigando outras vidas antípodas, lá estava a casa do orfanato, onde meninas silenciosas, vestidas de xadrez, aprendiam a trabalhar, a coser, a tecer as rendas dos enxovais de noiva que nós vestiríamos mais tarde, a bordar as camisas dos filhos que nós teríamos porque elas eram pobres no mundo e aprendiam justamente a viver e a penar como pobres. 
Uma proibição tradicional, baseada em não sei que remotas e complexas razões, nos separava delas. Só a víamos juntas na capela, alinhadas nos seus bancos do outro lado do corredor, quietinhas e de vista baixa, porque as regras que Ihes exigiam modéstia, humildade e silêncio eram ainda mais severas do que as nossas (QUEIROZ, 1996, p. 12).

Passados muitos anos e com várias reformas no CIC, o espaço narrado por Rachel de Queiroz não se distanciava muito, em termos de distinção, do espaço construído na metade do século XIX. As "remotas e complexas razões" da separação das meninas estão inscritas na produção social da distinção. Ou seja, as diferenças nas roupas, nos assentos e nos jeitos de falar não são meros instantâneos da realidade, são partes constituintes de um longo processo de afirmação das desigualdades (que tanto unem quanto segregam), não se limitando ao plano econômico. A pauperização evidente das órfãs mantida no cotidiano do recolhimento lançava sobre elas uma imediata identificação com o trabalho, de maneira que - a despeito da educação considerada privilegiada que recebiam - estaria solidificada no ambiente privado do Colégio uma mensagem tornada pública sobre o lugar social das órfãs no campo produtivo, na lógica do trabalho. É claro que as pensionistas teriam roupas e aposentos melhores por estarem pagando por isso, ao passo que as meninas órfãs ficavam com as doações que o Colégio recebia. Mas essa separação era também simbólica. Marcava a diferença entre aquelas cujo lugar no mundo era o da "elevada" senhora-mãe-de família das outras (órfãs e pobres) para quem o trabalho era apresentado como condição inerente.

Foram inúmeros os momentos em que essas diferenças se declararam. O olhar sobre as órfãs que, aparentemente, congregavam com as famílias ricas da cidade, com figuras importantes do meio social, como o bispo, abre questionamentos sobre os usos possíveis do recolhimento, sobre a atuação das meninas no espaço vigiado, sobre como as "aparências hegemônicas", que tendem a esconder as resistências e "discursos ocultos" dos subordinados - utilizando a reflexão de James Scott (2013) - foram ali construídas e desafiadas.

O ensino para as órfãs estava assim dividido: "1 - Catecismo, História Pátria, História Sagrada, Aritmética, Língua Vernácula e Francês; 2 - Costuras, bordados, flores, sapatos, consertos de roupas; 3 - Lavar e engomar com o fim de saber mais tarde governar a casa", conforme consta no regulamento, extraído do livro de Soares (1990). Essa última parte era exclusividade das órfãs, que lavavam as roupas das pensionistas. Quase toda limpeza do Colégio também era realizada pelas crianças pobres. O mesmo regimento 
declarava que os trabalhos eram divididos conforme a idade e capacidade física e intelectual das meninas. Entretanto, as descrições da rotina e uma ou outra denúncia nos jornais davam a ver um cotidiano repleto de tarefas árduas, que podiam extrapolar as demandas internas.

Em 1870, alguém sob o pseudônimo Olhos de Lince, perguntava se o bispo sabia que as órfãs do Colégio da Imaculada lavavam e engomavam a roupa dos seminaristas. Nessa publicação intitulada Pergunta Inocente, eram também contestadas as aulas práticas que as meninas recebiam sob a alegação de estarem sendo preparadas para se tornarem "respeitáveis mães de família". Indagava: "Será exato que as referidas órfãs aprendam a fazer sapatos e empalhar cadeiras? Realmente é uma educação muito necessária..."(Constituição, ed. 173, p. 3 1870).

A partir do questionamento de Olhos de Lince, posto no início dos anos 1870, é possível atentar para alguns aspectos importantes do cotidiano de trabalho das meninas recolhidas no CIC. Não era tão frequente o incômodo com a utilização da mão de obra de órfãs, especialmente considerando seu emprego em tarefas domésticas. A imposição do trabalho às órfãs pobres era mais criticada quando as meninas ficavam expostas no espaço público para cumprirem determinadas tarefas. Lavar roupas não era, nessa época, uma atividade do âmbito privado. Era preciso ir aos rios, segundo pesquisa realizada por Maia Neto (2015), que abordou o trabalho realizado pelos aguadeiros e pelas lavadeiras. Isso, de certo, era feito sob o olhar das Irmãs ou de alguma criada do Colégio. A presença das meninas na cena pública (provavelmente no riacho Pajeú, considerando a proximidade com o Colégio) reforçava a ideia de desigualdade construída no recolhimento vicentino. Por outro lado, demonstrava que o recolhimento não significava isolamento, havendo trocas e aprendizados que não estavam circunscritos ao interior do Colégio.

O modelo pensado pelas Irmãs de Caridade para a formação de donas de casa pobres e empregadas qualificadas, capazes de resolver pequenos reparos nas roupas, calçados e móveis, explicava as aulas que Lince julgou desnecessárias a uma mãe de família. Tais práticas se articulavam à profissionalização das meninas e, ao mesmo tempo, dialogavam com as demandas urbanas, com os ideais de civilidade que difundiam novos comportamentos esperados (refletidos nas roupas, na arrumação das casas, na divulgação das noções de higiene). Sobre essa mudança nas casas e bens de consumo, que caracterizou o "morar à francesa", Simone Santos (2016), fez uma análise da multiplicação de tarefas 
domésticas nos oitocentos, contextualizando a diversificação dos móveis e artefatos de decoração (vidros, assoalhos, tapetes, cortinas, espelhos), o que exigiu um trabalho de limpeza mais constante e especializado. O conjunto desses saberes e a forma como foram construídos pelas Irmãs Vicentinas revelam um processo de "escolarização do doméstico", no qual as tarefas da dona de casa passaram a ser reconfiguradas. Ou melhor, o trabalho doméstico foi sistematizado, teorizado.

Guacira Louro e Dagmar Meyer (1993) propuseram o termo "escolarização do doméstico" para tratar da construção e reformulação dos fazeres domésticos em saberes escolares. Esse processo histórico esteve diretamente associado às mudanças econômicas e culturais nas noções de família (valorização do doméstico, normatização dos espaços privados e interferências do Estado - medicina e instrução pública - na composição dos lares desde meados do século XIX), bem como na idealização das relações de gênero, atribuindo às mulheres a economia doméstica. As autoras desenvolveram a análise tomando como objeto de estudo a fundação de uma escola técnica voltada para o público feminino no Rio Grande do Sul na década de 1940. Apontaram para a complexidade do currículo ali elaborado, no qual as tarefas de lavar, passar, cozinhar não foram tomadas como naturais, mas foram racionalizadas e tecnificadas de forma a tornar mais eficiente, para os padrões da época, o serviço doméstico. O texto debate, então, os caminhos pelos quais as tarefas de casa se encontraram com os conhecimentos científicos, acadêmicos e as diversas tensões que se originaram desse encontro. Assim, "a designação da escola como espaço apropriado para este ensino, ao mesmo tempo que atribuía a ele um valor maior, implicava o reconhecimento da incompetência do lar para sua transmissão" (LOURO; MEYER, 1993, p.50). Retém-se este argumento para pensar nas razões que direcionavam as aulas práticas das alunas pobres do Colégio da Imaculada. Antes, porém, vale pontuar que o internamento de meninas ricas também interferia na dinâmica familiar das camadas abastadas.

O que significava, na metade dos oitocentos, a escolarização do doméstico?

Todo o projeto educacional das Vicentinas se inseria nas mudanças com relação às responsabilidades femininas, no lar, na religião e no espaço público em curso na segunda metade do século XIX. As pensionistas eram educadas para atingir modelos ideias de mulher - mãe instruída para melhor orientar os filhos, dona de casa preparada para receber visitas, coordenar o serviço doméstico, implantar boas práticas de asseio, além de possuir certos 
domínios da cultura letrada para não parecer ignorante nos aspectos atribuídos à civilidade (música, literatura, moda). Obviamente, não se tratava de uma simples transposição do ideário citadino identificado com a urbanidade para a sistematização dos conteúdos escolares. Mesmo porque o ensino confessional travou embates com diversas noções de modernidade no século XIX, consideradas ofensivas à moral cristã. Ainda assim, a incorporação de uma série de elementos atrelados ao saber médico-higienista, às aspirações de melhoramento e saneamento social e ao "embelezamento" da cidade e das casas legitimava a autoridade das Irmãs na formação de uma nova geração de mulheres compatível com a "prosperidade" urbana, sem desconsiderar os preceitos religiosos. Dessa forma, as pensionistas eram socializadas nos códigos daquilo que se dizia ser uma nova cultura urbana, em oposição ao passado da Província, agora chamado de arcaico, no contexto de reformulação urbanística de Fortaleza.

Uma imagem literária que representa bem o que seria essa transformação educacional das meninas ricas do $\mathrm{CIC}$ foi fornecida por Oliveira Paiva, no romance $A$ Afilhada, publicado em 1889 como folhetim no jornal O Libertador. A personagem Maria das Dores, filha de um desembargador, fora matriculada desde criança no Colégio da Imaculada. O contraste que o escritor estabeleceu entre a moça educada pelas Vicentinas francesas e sua mãe exemplifica o processo de assimilação de novos comportamentos e hábitos domésticos. Na trama, quando Maria das Dores terminou seus estudos no Colégio, passava o tempo lendo romances, bordando, tocando piano e conversando longamente com o pai sobre ciências e bastidores da política local, enquanto esperava cartas de seu amado. Sua mãe, Dona Fabiana, "sertaneja", "de fala gorda", passava o dia berrando com os criados, mas quando estava de bom humor, "sentava-se no quintal, em uma cadeira, com uma perna sobre a outra, (...) expansiva como a galinha choca esponjando-se na cinza" (PAIVA, 1993, p. 282). A contraposição entre Fabiana e sua filha Das Dores que percorre o romance de Oliveira Paiva é útil para entender o propósito da escolarização do doméstico na educação vicentina para meninas ricas: formar uma dona de casa para a "alta sociedade", vinculando os saberes-fazeres domésticos à distinção social.

Essa mesma racionalização sobre os trabalhos da casa ganhou uma outra finalidade no recolhimento de órfãs: a profissionalização do doméstico. Mudando o público, mudavam as feições e funções da escolarização do doméstico. Ainda que existissem várias intercessões 
nos princípios educativos que norteavam o cotidiano do Colégio da Imaculada, as aulas práticas direcionadas às meninas pobres tinham a intenção de promover a empregada doméstica exemplar, capaz de entender e cumprir bem as orientações da dona de casa exemplar, ambas idealizadas para contribuir com as novas disposições sociais que a modernidade/civilidade exigia. Assim, a profissionalização do doméstico era mais do que aprender o "bem-limpar", ensinado como conhecimento teórico e prático, avaliado, organizado em etapas e com diferentes graus de complexidade. Era, além de tudo isso, articular as técnicas do serviço doméstico agora escolarizado com as posturas desejáveis para o convívio numa sociedade "civilizada" e ordeira. Por isso, as meninas órfãs também tinham aulas de francês. Por isso, aprendiam a consertar sapatos e empalhar cadeiras.

É importante discutir esse processo de escolarização/profissionalização das atividades domésticas porque mostrou ações objetivas de normatização do emprego feminino. Este artigo analisa como o recolhimento de meninas pobres em Fortaleza foi atrelado a profissionalização, imputando a estas crianças a obrigação econômica e moral de trabalhar. No recolhimento, foi priorizada a ideia de profissionalização, o que correspondia ao combate à vadiagem, à internalização da disciplina e do tempo produtivo e às ideias de condicionamento social frente às novas estruturas econômicas, aspectos que marcaram as políticas públicas e assistencialistas no Brasil durante esse período.

\section{As Irmãs Vicentinas e o mercado de trabalho feminino no Ceará Oitocentista}

As Irmãs, em contato com o bispo, padres e famílias ricas locais construíram uma importante rede de apoio, garantindo doações, encomendas de trabalhos, assistência médica e possibilidades de engajar as moças em atividades remuneradas. A constituição dessa rede de apoio deveu-se, em grande parte, à relativa independência que as congregações femininas, principalmente aquelas voltadas ao assistencialismo, conquistaram no século XIX. Como observou Rosado Nunes (1997), as religiosas, exercendo cargos de direção em colégios, hospitais e missões, construíram no corpo organizacional da Igreja certa autonomia para si e para outras senhoras católicas, à medida que criavam espaços de atuação feminina nas obras de caridade. A autora lembrou ainda que essas entidades religiosas foram tomadas como sociabilidades, demarcando a presença de mulheres no espaço púbico, ainda que vinculado à uma definição conservadora do lugar social feminino. A composição desse circuito de informações, socorros, festas beneficentes, propiciou a 
circulação dos trabalhos das meninas internas e abriu caminhos para fixação das órfãs em postos de trabalho agenciados pelas Irmãs.

Todo o trabalho das órfãs era acertado pela direção do Colégio. Isso significava pouca chance de escolha das meninas no universo do recolhimento, mas, em contrapartida, a saída das órfãs do $\mathrm{ClC}$ não implicava em abandono, como se tivessem que se virar por conta própria depois de anos internadas. Rachel de Queiroz ajuda a levantar hipóteses sobre como as irmãs de caridade intermediavam o emprego de internas em casas de famílias ricas. No romance As três Marias, a história da órfã Hosana faz lembrar o rigor das tarefas na dinâmica do recolhimento e as formas possíveis de saída das meninas para o mercado de trabalho. A garota de aparência frágil, "bordava coisas lindíssimas com aqueles dedos magros, compridos, pepinados pela agulha" (QUEIROZ, 1996, p. 21). Às escondidas, tornouse muito amiga de uma pensionista, desobedecendo uma das regras mais incisivas do Colégio. Descoberta a amizade proibida, Hosana foi mandada embora. As irmãs organizaram sua partida para Baturité, onde iria bordar o enxoval de uma noiva rica e lá ficaria como criada. Tempos depois, ela se casou com um viúvo, homem pobre e carregado de filhos.

O destino imaginado para Hosana não parece tão improvável em se tratando do recolhimento de órfãs no período abordado por este estudo. De certo, as habilidades das meninas - treinadas, vigiadas e excessivamente avaliadas pelas Vicentinas - foram capitalizadas para angariar recursos aplicados na manutenção do Colégio. Além disso, o aprendizado desses ofícios conferia às órfãs um meio de vida, que, mesmo quando criadas de algum domicílio e enfrentando longas jornadas de trabalho, poderiam obter ganhos extras com as obras de agulha. Mas, entre esses fatores, destaca-se a mediação das freiras na inserção das órfãs no mundo do trabalho. Afinal, além de qualificadas, estavam sob recomendação das Irmãs, o que presumia serem obedientes, laboriosas e moralmente aceitáveis.

Ao longo dos anos diversos eventos sociais, como as festas de premiação das alunas pensionistas, quermesses marianas no mês de maio e jantares beneficentes foram dando visibilidade ao Colégio da Imaculada e funcionaram também como apresentação dos ofícios praticados pelas órfãs, como uma espécie de publicidade da "perfeição e bom gosto de muitos difíceis trabalhos" orientados pelas Vicentinas, como fazia notar o jornal $A$ Constituição, noticiando a festa do fim de ano de 1876. Naquele dia, depois de laureadas as 
pensionistas, abriu-se uma exposição de costuras, tapeçaria e bordados confeccionados pelas meninas recolhidas (Constituição, ed. 141, p.2, 13 dez. 1876). As obras de caridade em que as Filhas de São Vicente se envolviam geravam intercâmbios de trabalhos, donativos e favores, propiciando a ampliação das encomendas - o que significava muito trabalho para as órfãs - e a circulação por diferentes localidades da produção interna do CIC.

Esse movimento de encomendas de enxovais, objetos decorativos para festas, confecção de artigos para fins beneficentes contribuía para consolidar no recolhimento um processo de sistematização da produção e de disciplinarização do trabalho, considerando as exigências dos clientes, os prazos de entrega dos pedidos e a conciliação das oficinas com aulas e momentos de oração. O cotidiano de ensino/trabalho/oração, severamente regido pelas freiras, expõe as estratégias institucionais de combate ao ócio, investindo na repetição para forjar nas internas um uso "responsável" do tempo, todo ele preenchido com coisas sagradas e com lições de valorização do trabalho e da honra feminina. O ritmo de trabalho imposto às órfãs não só acarretava uma alteração em seus corpos - treinados e marcados pelo trabalho - como implicava mudanças de longo alcance em seus modos de vida, apartadas que estiveram, durante tantos anos, dos familiares.

Uma outra reflexão oportunizada pela leitura do romance de Rachel de Queiroz seria o estranhamento sentido pela personagem Guta quando visitava a casa paterna, na região do Cariri. Muito pequena fora enviada ao Colégio da Imaculada com os esforços do pai e da madrasta, que viviam de forma modesta para custear sua permanência no internato. Quando falava de sua família, Guta demonstrava certo distanciamento, como se não pertencesse mais àquele ambiente doméstico. Dizia: "Os meus moram tão longe, têm uma vida tão distante e separada! Mal conheço aqueles meninos lentos, redondos e chorões; aquela senhora gorda, sempre grávida ou sempre amamentando, que me recebe amavelmente quando chego das férias" (QUEIROZ, 1996, p. 38). Esse estranhamento dado a ver pela sensibilidade de Rachel de Queiroz foi selecionado aqui porque sugere os efeitos do recolhimento na vida das crianças órfãs ou separadas de seus pais. No romance, Guta só ia para casa uma vez por ano, por causa da distância. Isso fragmentava o convívio familiar, gerando algum desconforto por não se integrar ao fluxo rotineiro da casa. As órfãs jamais iam para casa; algumas nem tinham casa. Ressalta-se que o recolhimento tinha intenção declarada de romper certos hábitos familiares, impedindo o encontro das crianças pobres 
com seus parentes. Assim, é possível afirmar que a socialização das meninas no interior do Colégio, a forma como aprenderam seus ofícios, como experenciaram o tempo afetavam, conscientemente ou não, os laços familiares. Ou seja, se o trabalho era percebido e executado de maneira diferente, se as formas de falar, vestir e comer foram transformadas, as meninas recolhidas tiveram que (re)inventar identificações com seus parentes e demais grupos de interação. Com isso, não se sugere, absolutamente, que o modelo educacional praticado no orfanato foi absorvido de forma integral pelas crianças. Pretende-se destacar as contradições que povoavam o universo do recolhimento. Nesse sentido, não cabe nem uma vitimação das garotas internadas - como se os maus tratos e a infelicidade definissem por completo o internamento - e nem uma idealização das resistências empreendidas no contexto orfanológico. Não é possível analisar se as meninas órfãs egressas do $\mathrm{ClC}$ experenciaram mais ou menos liberdade nos trabalhos e lugares que passaram a frequentar longe do orfanato. Certamente, enfrentaram outros tipos de medo, ingressaram em outras relações de mandonismo e construíram outras redes de convívio e resistências. Mas operacionalizaram tudo isso com os códigos, saberes e sentimentos vivenciados e apropriados na rotina do recolhimento.

Além dos possíveis trabalhos como costureiras, lavadeiras, engomadeiras ou criadas, a atuação das Vicentinas em Fortaleza também favoreceu a circulação de órfãs dentro das instituições de caridade, como o hospital da Santa Casa de Misericórdia. Desde a década de 1870, nota-se na documentação consultada a presença de meninas órfãs junto às Irmãs na Santa Casa. Argos Vasconcelos (1994) afirmou que algumas órfãs foram recolhidas no período da seca de 1877 e que, posteriormente, durante a administração da Irmã Chousioux (madre superiora entre 1884-1901) um orfanato foi fundado, abrigando elevado número de meninas durante mais de vinte anos. Entretanto, mesmo antes da formalização do orfanato (cujo documento oficial de inauguração data de 1900) diversas meninas trabalhavam no serviço de limpeza, costura e na cozinha da Santa Casa. Não é improvável que o bispo tenha autorizado a saída de órfãs mais velhas do Colégio para a Santa Casa, pois continuariam sobre a tutela das Vicentinas. Abria-se outro espaço de emprego da mão de obra feminina em Fortaleza.

Em comemoração ao aniversário de 28 anos do Colégio da Imaculada Conceição, o Monsenhor Hipolyto Gomes Brasil - na época, vigário geral da Diocese do Ceará - escreveu 
um breve histórico da instituição, elogiando o trabalho pedagógico das Filhas de São Vicente. Naquele ano (1893), contando com 16 irmãs de caridade, havia 115 pensionistas e 80 órfãs matriculadas no Colégio. Segundo seus cálculos, desde a fundação do CIC (1865) até aquele momento 938 meninas haviam sido internadas ali, sendo 582 pensionistas e 356 "órfãs desvalidas". Sobre as órfãs que saíram, Hipolyto Brasil mencionou que 14 entraram para Congregação de São Vicente de Paula, 62 se casaram fora do Colégio, 16 se casaram dentro do Colégio (recebendo um dote de duzentos mil réis e um enxoval) e 3 viraram professoras em casas particulares. Além destas, "14 ex-alunas da classe das órfãs" haviam sido admitidas como auxiliares ou adjuntas no Externato São Vicente (CIC, 1999, p. 83).

Esse quadro de egressas fornecido pelo sacerdote faz notar que muitas meninas permaneceram fortemente ligadas às Irmãs, como funcionárias do Colégio ou como freiras (número expressivo, visto que no mesmo período, somente seis pensionistas seguiram a vida religiosa). Entretanto, um número muito maior de garotas recolhidas se deparou com outros destinos, provavelmente ligados a profissões comuns, ao cotidiano doméstico, que por serem corriqueiros e esperados - não foram destacados naquela comemoração. Outro dado relevante é o que sugere a quantidade de casamentos. Observa-se que muitas delas se casaram depois que já tinham deixado o Colégio. Isso significa que ou voltaram para as casas de suas famílias ou saíram para trabalhar em outros lugares, casando-se posteriormente. Vários foram os indícios encontrados nesta pesquisa de que a maioria das meninas recolhidas no $\mathrm{CIC}$ não tinha parentes com quem pudesse contar: eram crianças cujos pais haviam morrido, que não conheceram tutores - a não ser o Juizado de Órfãos -, que foram apresentadas no Colégio por padres, que escaparam da seca ou que foram deixadas no recolhimento por parentes que não as tinham como sustentar. Nessas condições, acredita-se que quase todas elas arranjaram-se como criadas em casas particulares ou em estabelecimentos comerciais.

\section{Considerações Finais}

A proposta vicentina de preparar donas de casa e empregadas domésticas sugere dois movimentos concomitantes. Era uma educação para meninas pobres. Nesse sentindo, estava acomodada nos repertórios de segregação social próprios do século XIX: órfãs pobres, muitas delas pardas, preparadas para servir convenientemente às famílias ricas. Visto por esse ângulo, era um mecanismo de conservação da ordem social. Porém, eram, igualmente, 
ações de fuga da indigência, sobretudo se pensadas dentro desse mesmo contexto de infância pobre, convivendo com políticas de exclusão numa sociedade escravocrata. Não resta dúvida que para legisladores, juristas clássicos e para representantes da Igreja o recolhimento era mesmo uma medida de profilaxia social. Mas, à revelia, era, para os pobres, uma brecha de acesso ao mundo do trabalho qualificado que os diferenciava dos jornaleiros - trabalhadores sem qualificação que ganhavam por dia trabalhados -, podendo ser reinventado e transformado em ganhos financeiros e simbólicos.

A educação feminina nesse período era muito restrita. Por isso, considerava-se um privilégio receber a instrução rebuscada das Vicentinas. A análise proposta nestas páginas buscou considerar os tratamentos diferenciados entre meninas ricas e pobres no Colégio da Imaculada Conceição, destacando que os processos educacionais não estão apartados das questões de classe. Desta forma, defendeu-se que o orfanato dirigido pelas Irmãs de São Vicente de Paula na cidade de Fortaleza foi um espaço voltado à profissionalização de meninas pobres no contexto do século XIX. A história das mulheres reclusas ao lar não é a mesma história das mulheres da classe trabalhadora.

\section{REFERÊNCIAS BIBLIOGRÁFICAS}

CAULFIELD, Sueann. Em defesa da honra: moralidade, modernidade e nação no Rio de Janeiro. Tradução: Elizabeth Martins. Campinas: Unicamp, 2000.

COLÉGIO DA IMACULADA CONCEIÇÃO. Colégio da Imaculada Conceição: Do Gênese ao Apocalipse. Fortaleza: Tiprogresso, 1999.

ENGEL, Magali. Psiquiatria e feminilidade. In: Priore, Mary Del (Org.). História das mulheres no Brasil. São Paulo: Contexto/Unesp, 1997.

FONSECA, Jamily. Raça, Natureza e Sociedade: O pensamento evolucionista em Fortaleza na década de 1870. 2015. 164 f. Dissertação (Mestrado em História) - Universidade Federal do Ceará, Fortaleza, 2015.

LAGE, Ana Cristina Pereira. Conexões Vicentinas: Particularidades políticas e religiosas da educação confessional em Mariana e Lisboa oitocentistas. 246 f. Tese (Doutorado em Educação) - Universidade Federal de Minas Gerais, Belo Horizonte, 2011.

LINHARES, Juliana. Entre a Casa e a Rua: Trabalhadores pobres urbanos em Fortaleza (1871-1899). Dissertação (Mestrado em História) - Universidade Federal do Ceará, 2011.

LOURO, Guacira; MEYER, Dagmar. A escolarização do doméstico: A construção de uma escola técnica feminina (1946-1970). Cadernos de Pesquisa, São Paulo, no 87, p. 45-57, 1993. 
MAIA NETO, Emy Falcão. Cartografias da água: Territorialidades, políticas e usos da água doce em Fortaleza (1856 - 1926). 2015. 268 f. Tese (Doutorado em História) - Universidade Federal do Ceará, Fortaleza, 2015.

MARQUES. Vera Regina. A medicalização da raça: médicos, educadores e discurso eugênico. Campinas: Unicamp, 1994.

NEVES. Berenice de Abreu de Castro. "Intrépidos romeiros do progresso": os maçons no Império. In: SOUZA, S. e NEVES, F. (Orgs.) Intelectuais. Fortaleza: Demócrito Rocha, 2002.

NUNES, Maria José Rosado. Freiras no Brasil. In: Priore, Mary Del (Org.) História das mulheres no Brasil. São Paulo: Contexto/Unesp, 1997.

PAIVA, Oliveira. A Afilhada. In: Obra Completa. Rio de Janeiro: Gráfica Editorial, 1993.

QUEIROZ, Rachel. As Três Marias. Fortaleza: Casa de José de Alencar, 1996.

SANT'ANNA, Denise. Higiene e higienismo entre o Império e a República. In: PRIORE, M. e AMANTINO, M. (Orgs.) História do corpo no Brasil. São Paulo: Unesp, 2011.

SANTOS, Simone Andriani dos. Identidade, gênero e cultura material: senhoras e criadas no espaço doméstico - São Paulo (1870-1920). Revista de Crítica Cultural, v. 4, n. 2, 2016.

SCOTT, James. A Dominação e a arte da resistência. Lisboa: Letra Livre, 2013.

SOARES, Maria Norma Maia. Colégio da Imaculada Conceição: Roteiro para uma visita ao passado. Fortaleza: Editorial Cearense, 1990.

SOUZA, Jessie Jane. Círculos Operários: a Igreja Católica e o mundo do trabalho no Brasil. Rio de Janeiro: Faperj, 2002.

VASCONCELOS, Argos. Santa Casa de Fortaleza (1861-1992). Fortaleza: Gráfica Batista, 1994. 